\title{
PENYALAHGUNAAN WEWENANG DALAM TINDAK PIDANA KORUPSI SETELAH BERLAKUNYA UU NO. 30 TAHUN 2014 TENTANG ADMINISTRASI PEMERINTAHAN
}

\author{
Zulkarnaen \\ Prodi Magister Hukum, Fakultas Hukum-Universitas Mataram NTB \\ zulkarnaen_mih15@gmail.com \\ Zainal Asikin \\ Dosen Fakultas Hukum-Universitas Mataram NTB \\ asikinzainalfh@unram.ac.id \\ Amiruddin \\ Dosen Fakultas Hukum-Universitas Mataram NTB \\ amiruddin_mih@yahoo.co.id
}

\begin{abstract}
This research was conducted to find out how the concept of abuse of authority in criminal acts of corruption after the enactment of Law Number 30 of 2014 concerning Government Administration; and How was law enforcement in handling criminal acts of corruption after the enactment of the Law Number 30 of 2014. This research was a normative legal research. The approach used in this research was the statutory approach, the conceptual approach, and the comparative approach. From the results of the study it could be concluded that the concept of abuse of authority in criminal acts of corruption after the entry into force of Law Number 30 of 2024 concerning Government Administration was the Abuse of authority in accordance with Article 17 of Law No. 30 of 2014. Law No. 30 of 2014 focused on preventing abuse of authority. Aspects of criminal acts of corruption were first proven based on administrative law. In the process of law enforcement, if there was indeed an abuse of authority, then it became the basis by law enforcement officials to investigate or investigate allegations of corruption against the abusers of authority, whereas if in testing the abuse of authority by the State Administrative Court, the evidence was not proven, of course these actions could not be used as a basis for conducting investigations.
\end{abstract}

Keywords: Authority, corruption, government administration, law enforcement

Submitted: March 21, 2020

Reviewed: April 1, 2020

Published: June 1, 2020

How to Cite: Zulkarnaen, et.al. 2020. Konsep Penyalahgunaan Wewenang dalam Tindak Pidana Korupsi Setelah Berlakunya Undang-undang Nomor 30 Tahun 2014 Tentang Administrasi Negara 4(1): pp. 53-66. DOI: https://doi.org/ 10.24036/jess/vol4-iss1

\section{Pendahuluan}

Korupsi di Indonesia terus menunjukan peningkatan dari tahun ke tahun. Baik dari jumlah kasus yang terjadi maupun jumlah kerugian keuangan Negara. Kualitas peristiwa korupsi yang dilakukan juga semakin sistematis dengan lingkup yang memasuki seluruh aspek kehidupan masyarakat. Kondisi tersebut menjadi salah 
satu faktor utama penghambat keberhasilan untuk mewujudkan masyarakat Indonesia yang adil dan makmur sebagaimana diamanatkan oleh undang-undang dalam memberantas korupsi. Salah satu agenda reformasi yang direncanakan oleh para reformis adalah memberantas Korupsi, Kolusi dan Nepotisme (KKN). Pada waktu digulirkannya reformasi ada suatu keyakinan bahwa peraturan perundangan yang dijadikan landasan untuk memberantas korupsi dipandang tidak sesuai dengan kebutuhan masyarakat. Hal tersebut dapat dilihat dalam Ketetapan Majelis Permusyawaratan Rakyat Republik Indonesia Nomor XI/MPR/1998 tentang Penyelenggaraan Negara Yang Bersih dan Bebas Korupsi, Kolusi dan Nepotisme.

Selain itu di dalam Pasal 3 Undang-Undang Nomor 31 Tahun 1999 tentang Pemberantasan Tindak Pidana Korupsi, sebagaimana telah diubah dengan Undangundang Nomor 20 Tahun 2001 tentang Perubahan atas Undang-undang Nomor 31 Tahun 1999 tentang Pemberantasan Tindak Pidana Korupsi (UU Pemberantasan Tipikor) jo. Pasal 5 dan Pasal 6 UU Nomor 46 Tahun 2009 tentang Pengadilan Tindak Pidana Korupsi (UU Pengadilan Tipikor), yang salah satu unsurnya adalah menyalahgunakan kewenangan, dimana kompetensi absolut untuk memeriksa masalah tersebut diberikan kepada Pengadilan Tindak Pidana Korupsi.

Tindak pidana korupsi yang sering terjadi merupakan permasalahan nasional yang harus dihadapi secara sunguh-sungguh, upaya penanggulangan melalui keseimbangan langkah-langkah yang tegas dan jelas melibatkan semua potensi yang ada dalam masyarakat khususnya pemerintah dan aparat penegak hokum (Dinar dan Fadillah, 2009). Masalah korupsi bukan masalah baru dalam persoalan hukum dan ekonomi bagi suatu negara, karena masalah korupsi sudah ada sejak ribuan tahun yang lalu, baik di negara maju maupun di negara berkembang termasuk juga di Indonesia. Korupsi telah merayap dan menyelinap dalam berbagai bentuk, atau modus operandi sehingga mengakibatkan kerugian keuangan negara, perekonomian negara dan merugikan kepentingan masyarakat (Nurjana, 2010).

Peristiwa korupsi selalu menjadi perhatian yang lebih dibandingkan dengan peristiwa lain di berbagai belahan dunia. Fenomena ini dapat dimaklumi mengingat dampak negatif yang ditimbulkan oleh peristiwa ini. Dampak yang ditimbulkan dapat menyentuh berbagai bidang kehidupan. Korupsi merupakan masalah serius, karena dapat membahayakan pembangunan sosial ekonomi dan juga politik, serta dapat merusak nilai-nilai demokrasi dan moralitas karena perbuatan ini seakan menjadi sebuah budaya. Korupsi merupakan ancaman terhadap cita-cita menuju masyarakat adil dan makmur.

Pembicaraan tentang korupsi seakan tidak ada putus-putusnya. Fenomena ini memang sangat menarik untuk dikaji, apalagi dalam situasi seperti sekarang ini, dimana ada indikasi yang mencerminkan ketidakpercayaan rakyat terhadap pemerintah. Tindak pidana korupsi yang sering terjadi merupakan permasalahan nasional yang harus dihadapi secara sunguh-sungguh, upaya penanggulangan melalui keseimbangan langkah-langkah yang tegas dan jelas melibatkan semua potensi yang ada dalam masyarakat khususnya pemerintah dan aparat penegak hukum.

Perbuatan menyalahgunakan kewenangan sebagaimana diatur dalam Undang-undang Republik Indonesia Nomor 31 Tahun 1999 sebagaimana telah diubah dengan Undang-undang Republik Indonesia Nomor 20 Tahun 2001 juga 
diatur dalam Undang-Undang Republik Indonesia Nomor 30 tahun 2014 tentang Administrasi Pemerintahan yang menyebutnya dengan Penyalagunaan Wewenang. Dalam penegakan hukum terhadap penyelenggara pemerintahan, maka Undangundang Nomor 30 Tahun 2014 tentang Adminitrasi Pemerintahan menjadi landasan baru bagi Pengadilan Tata Usaha Negara dalam menguji sengketa Tata Usaha Negara tentang penyalahgunaan wewenang yang dilakukan oleh penyelenggara pemerintahan dan harus dibuktikan di Pengadilan Tata Usaha Negara.

Tujuannya yaitu pengaturan yang jelas terhadap tata tertib administrasi pemerintah dalam menjalankan pemerintahan seperti mengatur kewenangan, jenisjenis keputusan, sistem dan model pengujian keputusan, sanksi administrasi dan lain-lain. Permasalahan timbul karena konsep "penyalahgunaan wewenang" dalam diundangkannya Undang-Undang Administrasi Pemerintahan oleh beberapa ahli hukum dipandang sama dengan konsep "menyalahgunakan kewenangan" karena jabatan dalam diundangkannya Undang-Undang Pemberantasan Tindak Pidana Korupsi. Ketentuan tersebut berpotensi menimbulkan sengketa kewenangan absolut antara Peradilan Tindak Pidana Korupsi dan Peradilan Administrasi. Untuk itu, unsur menyalahgunakan kewenangan dalam Tindak Pidana Korupsi (Tipikor) sebagai kompetensi absolut Peradilan Administrasi menarik untuk dikaji.

Dengan adanya conflict norm pasca diundangkannya Undang-Undang Nomor 30 Tahun 2014 tentang Administrasi Pemerintahan, yaitu Pasal 17 sampai dengan Pasal 21, yang mengatur tentang larangan penyalahgunaan wewenang oleh Badan dan/atau Pejabat Pemerintahan serta pemberian kewenangan kepada Aparat Pengawasan Intern Pemerintah (APIP) dan Peradilan Tata Usaha Negara (Peradilan Administrasi) untuk melakukan pengawasan dan pengujian mengenai ada atau tidak adanya unsur penyalahgunaan wewenang dilakukan oleh Pejabat Pemerintahan. Sementara sebelumnya telah ada ketentuan Pasal 3 Undang-Undang Nomor 31 Tahun 1999 tentang Pemberantasan Tindak Pidana Korupsi, sebagaimana telah diubah dengan Undang-Undang Nomor 20 Tahun 2001 (Undang-Undang Pemberantasan Tipikor) jo. Pasal 5 dan Pasal 6 Undang-Undang Nomor 46 Tahun 2009 tentang Pengadilan Tindak Pidana Korupsi (Undang-Undang Pengadilan Tipikor), yang salah satu unsurnya mengatur Tipikor karena menyalahgunakan kewenangan, dimana kompetensi absolut untuk memeriksa masalah tersebut diberikan kepada Pengadilan Tipikor.

Ketentuan dalam Undang-undang Administrasi Pemerintahan tersebut telah menimbulkan pro kontra diantara para Ahli Hukum, khususnya Ahli Hukum Pidana dan Ahli Hukum Administrasi Negara berkenaan dengan keberlakuan ketentuan dimaksud dan pengaruhnya terhadap kewenangan Peradilan Tindak Pidana Korupsi. Berdasarkan uraian di atas, tulisan ini membahas tentang bagaimana konsep penyalahgunaan wewenang dalam tindak pidana korupsi setelah berlakunya UU No. 30 Tahun 2014 tentang Administrasi Pemerintahan.

\section{Metode Penelitian}

Penelitian ini merupakan penelitian hukum normatif, yaitu penelitian yang dilakukan terhadap asas-asas hukum, kaedah-kaedah hukum dalam arti nilai (norma), peraturan hukum konkrit dan sistem hukum, yang berhubungan dengan materi yang diteliti. Penelitian hukum normatif atau disebut juga penelitian hukum 
doktrinal. Pendekatan yang digunakan dalam penelitian ini adalah pendekatan perundang-undangan (statuta approach). Menurut Ibrahim (2007) suatu penelitian normatif tentu harus menggunakan pendekatan perundang-undangan, karena yang akan diteliti adalah berbagai aturan hukum yang menjadi fokus sekaligus tema sentral suatu penelitian. Pendekatan Konsep (conceptual approach) merupakan pengertian yang relevan adalah unsur-unsur abstrak yang mewakili fenomena dalam suatu bidang studi, logis yang menarik perhatian dari sudut pandangan praktis dan sudut pengetahuan dalam pikiran tertentu. Pendekatan perbandingan (comparative approach) merupakan salah salah satu cara yang digunakan dalam penelitian hukum normatif untuk membandingkan salah satu lembaga hukum (legal institutions) dari sistem hukum yang satu dengan lembaga hukum yang kurang lebih sama dari sistem hukum yang lain.

Cara atau teknis pengumpulan bahan hukum yang digunakan adalah studi dokumentasi yakni dengan mencatat informasi dari bahan hukum yang berkaitan Konsep Penyalahgunaan Wewenang Dalam Tindak Pidana Setelah Berlakunya Undang-Undang Nomor 30 Tahun 2014 Tentang Administrasi Negara, baik secara normatif maupun berupa ide atau gagasan. Pencatatan ini dilakukan secara selektif untuk mendukung dan melengkapi bahan hukum yang diperoleh dari sumber lain. Seluruh bahan hukum yang diperoleh dari penelitian kepustakaan selanjutnya akan dianalisis secara deduktif dengan membangun argumen berdasarkan kepada logika berpikir, juga melakukan penafsiran terhadap berbagai bahan hukum (Nasution, 1992); sehingga diperoleh jawaban atas permasalahan secara akurat dan komprehensif.

\section{Konsep Penyalahgunaan Wewenang dalam Tindak Pidana Korupsi Berdasarkan UU No. 30 Tahun 2014 tentang Administrasi Pemerintahan}

Sebagai sebuah negara hukum kesejahteraan yang dianut di Indonesia, maka tugas utama pemerintah untuk mewujudkan tujuan negara salah satunya melalui pelayananan publik. Namun, korupsi di negeri ini semakin beragam, pejabat birokrasi pemerintahan menjadi sorotan, karena mereka sebagai pejabat publik yang menjalankan roda administrasi pemerintahan sangat rawan terhadap praktikpraktik korupsi. Hal yang perlu dipahami adalah bahwa pejabat birokrasi memiliki kewenangan yang dijamin oleh undang-undang dalam menjalankan administrasi pemerintahan, seringkali keputusan para pejabat birokrasi melampaui kewenangan yang diberikan undang-undang dan etika birokrasi. Undang-Undang Nomor 30 Tahun 2014 tentang Administrasi Pemerintahan (UU No. 30 Tahun 2014), sebagaimana tercantum dalam Pasal 3, menjelaskan bahwa salah satu tujuan undang-undang ini adalah mencegah terjadinya penyalahgunaan wewenang. Lebih lanjut UU No. 30 Tahun 2014 mengatur larangan penyalahgunaan wewenang pada Pasal 17 sampai dengan Pasal 21.

Uraian Pasal 17 sampai dengan Pasal 21 UU No. 30 Tahun 2014 tentang Administrasi Negara di atas menunjukan pengaturan larangan perbuatan penyalahgunaan wewenang, pengawasan sampai pada proses peradilan pejabat yang teramsuk dalam kategori penyalahgunaan wewenang, mencermati penagturan tersebut, terdapat perbedaan dengan pengaturan UU No. 39 Tahun 1999 jo. UU No. 20 Tahun 2001 tentang Pemberantasan Tindak Pidana Korupsi. 
UU No. 30 Tahun 2014 lebih menekankan pada pencegahan penyalahgunaan wewenang, sehingga aspek tindak pidana korupsi terlebih dahulu dibuktikan aspek administrasi. Apabila ditemukan terjadinya penyalahgunaan wewenang yang memenuhi unsur dalam UU Tipikor maka dilakukan proses peradilan tindak pidana korupsi. Berdasarkan pengaturan UU No. 30 Tahun 2014 di atas memungkinkan pula penyelesaian berdasar hukum administrasi negara untuk membuktikan adanya penyalahgunaan wewenang, sehingga proses penyelesaian tindak pidana korupsi berdasar UU Tipikor ditempuh setelah terbukti adanya penyalahgunaan wewenang yang dilakukan oleh PTUN, UU No.30 Tahun 2014 sekaligus telah memperluas kompetensi PTUN. Dengan demikian terjadi pergeseran penyelesaian yang terlebih dahulu ditempuh penyelesaian berdasar hukum administrasi.

Kompetensi PTUN yang telah diperluas sehubungan dengan pemberlakuan UU No. 30 Tahun 2014 tentang Administrasi Pemerintahan adalah memeriksa, mengadili dan memutus: a. Perbuatan Badan dan/ atau Pejabat Pemerintahan dalam mengeluarkan keputusan administrasi pemerintahan (beschikkingsdaad); b. tindakan Pejabat Pemerintahan atau penyelenggara negara lainnya dalam melakukan dan/atau tidak melakukan perbuatan konkret/faktual (materieele daad). Ketentuan dalam Pasal 21 ayat (2) UU No. 30 Tahun 2014 tentang Administrasi Pemerintahan menentukan yang menjadi subjek pemohon untuk mengajukan permohonan pengujian ada atau tidak ada unsur penyalahgunaan wewenang ke PTUN adalah "Badan dan/ atau Pejabat Pemerintahan". Rumusan ini sudah lex certa tidak terjadi multi tafsir siapa yang menjadi Pemohon (Marzuki, 2017).

Permasalahan yang menjadi multi tafsir adalah mengenai "keputusan dan/ atau tindakan" Pejabat Pemerintahan yang manakah yang menjadi objek permohonan: apakah keputusan dan/atau tindakan Badan dan/atau Pejabat Pemerintahan yang mengajukan permohonan itu sendiri; keputusan dan/atau Tindakan Pejabat Pemerintahan lain; dan/atau kedua-duanya baik Badan/atau Pejabat Pemerintahan itu sendiri dan Badan dan/atau Pejabat Pemerintahan yang lain. Adanya Pasal 21 UU No. 30 Tahun 2014 tentang Administrasi Pemerintahan, pengujian terhadap ada tidaknya unsur penyalahgunaan wewenang menjadi kewenangan dan diuji terlebih dahulu di PTUN memunculkan berbagai tafsir. Disatu sisi pemberian wewenang menguji terkait ada atau tidaknya unsur penyalahgunaan wewenang muncul karena UU No. 30 Tahun 2014 memberikan kewenangan kepada PTUN untuk menilai ada atau tidak adanya unsur penyalahgunaan wewenang. Pada sisi lain Pengadilan Tindak Pidana Korupsi berdasarkan kewenangan yang diberikan oleh UU No. 46 Tahun 2009 menguji ada atau tidak ada unsur menyalahgunakan kewenangan sebagai salah satu unsur di dalam Pasal 3 UU No. 20 Tahun 2001 tentang Pemberantasan Tindak Pidana Korupsi merupakan wewenang Pengadilan Tindak Pidana Korupsi.

UU No. 30 Tahun 2014 tentang Administrasi Pemerintahan maupun UU No. 20 Tahun 2001 tentang Pemberantasan Tindak Pidana Korupsi tersebut tidak saling menegasikan (meniadakan) kewenangan masing-masing. Kedua undang-undang ini tidak pula saling menunda kewenangan untuk melakukan pemeriksaan, sehingga muncul polemik pendapat mengenai pengadilan yang tepat untuk menilai ada atau tidak ada unsur penyalahgunaan wewenang yang dilakukan oleh Pejabat Pemerintah. 
Penyalahgunaan kewenangan dalam hukum administrasi dapat diartikan dalam 3 (tiga) wujud, yaitu:

1) Penyalahgunaan kewenangan untuk melakukan tindakan tindakan yang bertentangan dengan kepentingan umum atau untuk menguntungkan kepentingan pribadi, kelompok atau golongan;

2) Penyalahgunaan kewenangan dalam arti bahwa tindakan pejabat tersebut adalah benar ditujukan untuk kepentingan umum, tetapi menyimpang dari tujuan kewenangan yang diberikan oleh undang-undang atau peraturanperaturan lainnya;

3) Penyalahgunaan kewenangan dalam arti menyalahgunakan prosedur yang seharusnya dipergunakan untuk mencapai tujuan tertentu, tetapi telah menggunakan prosedur lain agar terlaksana.

Konsep penyalahgunaan wewenang dalam Hukum Adiministrasi Negara, menurut Basah (1985) dapat dibagi menjadi dua, yaitu:

1) Detournement de pouvoir atau melampaui wewenang/batas kekuasaaan. Berdasarkan pengertian dalam pasal 1 angka 3 Undang-undang No. 37 Tahun 2008 tentang Ombudsman Republik Indonesia yang menguraikan unsur dari pemenuhan suatu tindakan administrasi point kedua: "yang melampaui wewenang, atau menggunakan wewenang untuk tujuan lain dari yang menjadi tujuan wewenang tersebut, atau termasuk kelalaian atau pengabaian kewajiban hukum dalam penyelenggaraan pelayanan publik"

2) Abuse de droit atau sewenang-wenang, yaitu perbuatan pejabat yang tidak sesuai dengan tujuan di luar lingkungan ketentuan perundang-undangan. Pendapat ini mengandung pengertian bahwa untuk menilai ada tidaknya penyalahgunaan wewenang dengan melakukan pengujian dengan bagaimana tujuan dari wewenang tersebut diberikan (asas spesialitas). Bertindak sewenang-wenang juga dapat diartikan menggunakan wewenang (hak dan kekuasaan untuk bertindak) melebihi apa yang sepatutnya dilakukan sehingga tindakan dimaksud bertentangan dengan ketentuan.

Penyalahgunaan kewenangan sangat erat kaitan dengan terdapatnya ketidaksahan (cacat hukum) dari suatu keputusan dan atau tindakan pemerintah/ penyelenggara negara. Cacat hukum keputusan dan/atau tindakan pemerintah/ penyelenggara negara pada umumnya menyangkut tiga unsur utama, yaitu unsur kewenangan, unsur prosedur dan unsur substansi, dengan demikian cacat hukum tindakan penyelenggara negara dapat diklasifikasikan dalam tiga macam, yakni: cacat wewenang, cacat prosedur dan cacat substansi. Ketiga hal tersebutlah yang menjadi hakekat timbulnya penyalahgunaan kewenangan. Undang-Undang Nomor 30 Tahun 2014 tentang Administrasi Pemerintahan Pasal 17 di atas menyatakan larangan penyalahgunaan Wewenang meliputi larangan melampaui Wewenang; larangan mencampuradukkan Wewenang; dan/atau larangan bertindak sewenangwenang.

Badan dan/atau Pejabat Pemerintahan dikategorikan melampaui Wewenang sebagaimana dimaksud dalam Pasal 17 ayat (2) huruf a apabila Keputusan dan/atau Tindakan yang dilakukan: a. melampaui masa jabatan atau batas waktu berlakunya 
Wewenang; b. melampaui batas wilayah berlakunya Wewenang; dan/atau c. bertentangan dengan ketentuan peraturan perundang-undangan.

Badan dan/atau Pejabat Pemerintahan dikategorikan mencampuradukkan Wewenang sebagaimana dimaksud dalam Pasal 17 ayat (2) huruf b apabila Keputusan dan/atau Tindakan yang dilakukan: a. di luar cakupan bidang atau materi Wewenang yang diberikan; dan/atau b. bertentangan dengan tujuan Wewenang yang diberikan. Badan dan/atau Pejabat Pemerintahan dikategorikan bertindak sewenangwenang sebagaimana dimaksud dalam Pasal 17 ayat (2) huruf c apabila Keputusan dan/atau Tindakan yang dilakukan: a. tanpa dasar Kewenangan; dan/atau b. bertentangan dengan Putusan Pengadilan yang berkekuatan hukum tetap.

Pengaturan Pasal 17 UU No. 30 Tahun 2014 di atas memberikan penegasan penyalahgunaan wewenang yang juga disebutkan dalam Pasal 3 UU Tipikor yang tidak menguraikan lebih lanjut yang dimaksud penyalahgunaan wewenang. Dengan demikian UU No. 30 Tahun 2014 sekaligus memberikan kejelasan, namun di sisi lain perbuatan penyalahgunaan wewenang yang termasuk kategori UU No. 30 Tahun 2014 ditempuh penyelesaian administrasi guna membuktikan adanya penyalahgunaan wewenang, kemudian dikategorikan ataupun memenuhi unsur penyalahgunaan wewenang berdasar Pasal 3 UU Tipikor.

Penegasan pengaturan penyalahgunaan wewenang merujuk pada perbuatan maladministrasi menurut Pasal 1 angka 3 UU No. 37 Tahun 2008 tentang Ombudsman, bahwa maladministrasi adalah perilaku atau perbuatan melawan hukum, melampaui wewenang, menggunakan wewenang untuk tujuan lain dari yang menjadi tujuan wewenang tersebut, termasuk kelalaian atau pengabaian kewajiban hukum dalam penyelenggaraan pelayanan publik yang dilakukan oleh penyelenggara negara dan pemerintah yang menimbulkan kerugian materiil dan atau immaterial bagi masyarakat dan orang perseorangan. Komisi Ombudsman Nasional memberikan indikator bentuk-bentuk maladministrasi, antara lain melakukan tindakan yang janggal (inappropriate), menyimpang (deviate), sewenang-wenang (arbitrary), melanggar ketentuan (irregular), penyalahgunaan wewenang (abuse of power), atau keterlambatan yang tidak perlu (undue delay), dan pelanggaran kepatutan (equity).

Pelaksanaan maladministrasi seringkali dibenturkan dengan tindak pidana korupsi, bahkan para penegak hukum sendiri masih kesulitan membedakan dan membuktikan perbuatan maladministrasi dan korupsi, karena perbedaan keduaanya sangat tipis, bahkan ada pula maladministrasi yang masuk kategori korupsi. Menurut perspektif hukum, definisi korupsi secara gamblang telah dijelaskan dalam 3 buah Pasal dalam UU No. 31 Tahun 1999 yang telah diubah dengan UU No. 20 Tahun 2001 tentang Pemberantasan Tindak Pidana Korupsi. Berdasarkan pasalpasal sebagaimana diuraikan di atas, korupsi dirumuskan kedalam 30 bentuk/jenis tindak pidana korupsi. Pasal-pasal tersebut menerangkan secara terperinci mengenai perbuatan yang bisa dikenakan sanksi pidana karena korupsi. Ketigapuluh bentuk/jenis tindak pidana korupsi tersebut yaitu kerugian keuangan negara, suap-menyuap, penggelapan dalam jabatan, pemerasan, perbuatan curang, benturan kepentingan dalam pengadaan, dan gratifikasi. Kualifikasi tersebut dapat 
mengarah ataupun termasuk dalam kategori penyalahgunaan wewenang apabila memenuhi unsur yang dilakukan oleh PNS atau pejabat negara.

Berdasarkan hal tersebut, pengaturan dalam UU No. 30 Tahun 2014 juga perlu dilihat dari aspek maladministrasi, perbuatan maladministrasi dapat dikategorikan sebagai tindak pidana korupsi dan penyalahgunaan wewenang apabila merujuk pada Pasal 3 UU Tipikor. Namun, Tidak semua penyalahgunaan wewenang dalam hukum administrasi berujung pada penyalahgunaan wewenang dalam tindak pidana korupsi. Penyalahgunaan wewenang dalam hukum pidana hanya meliputi perbuatan pejabat administratif yang menyalahgunakan wewenang karena tidak adanya kewenangan yang bersangkutan untuk melakukan perbuatan tersebut. Sedangkan sisanya bukan penyalahgunaan wewenang dalam hukum pidana (Armono, 2014).

Dengan demikian, untuk mengetahui penyalahgunaan wewenang harus dilihat dari segi sumber wewenang berasal. Hukum administrasi di setiap penggunaan wewenang di dalamnya terkandung pertanggungjawaban, tapi tidak semua pejabat yang menjalankan wewenang itu secara otomatis memikul tanggung jawab karena harus dapat melihat apakah pejabat yang bersangkutan yang memikul jabatan tersebut, dari sudut pandang cara memperoleh dan menjalankan wewenang.

Parameter yang membatasi gerak bebas kewenangan aparatur negara (discretionary power) dalam perspektif hukum administrasi negara adalah detournament de povouir (penyalahgunaan wewenang) dan abus de droit (sewenang-wenang). Sementara itu, dalam kriteria perspektif hukum pidana yang membatasi gerak bebas kewenangan aparatur negara berupa unsur wederrechtlijkheid dan "menyalahgunakan wewenang". Permasalahan area hukum pidana tidak sesulit apabila dilakukan pembedaan sebagai titik singgung (grey area) antara hukum administrasi negara dengan hukum pidana, khususnya tindak pidana korupsi Adji. (2009).

Titik singgung antara hukum pidana dengan HAN bukan hanya dalam UU No. 20 Tahun 2001 tentang Pemberantasan Tindak Pidana Korupsi UU No. 20 Tahun 2001 tentang Pemberantasan Tindak Pidana Korupsi, tetapi juga dengan UU Keuangan Negara, UU Perbendaharaan Negara, maupun UU BPK. Secara teori dan praktik pembentukan peraturan perundang-undangan HAN sudah memasuki wilayah hukum pidana dan hukum perdata. Bahkan di beberapa Negara (Amerika, Inggris, dan Belanda) berdasarkan hasil penelitian Andhi Nirwanto (dalam Manao, 2018), penyelesaian tindak pidana adakalanya diselesaikan melalui sarana HAN, seperti kasus penyuapan dalam proyek penanaman kapas transgenic di Amerika melanggar foreign action act akan tetapi penegak hukum disana, yaitu Department of Justice Dengan Security Action Commission menyelesaikan masalah kerugian Negara dengan denda sebesar US 1,5 juta.

Ranah PTUN adalah penyalahgunaan wewenang, sedangkan ranah hukum tindak pidana korupsi adalah penyalahgunaan kewenangan (Pasal 3 UU No. 20 Tahun 2001 tentang Pemberantasan Tindak Pidana Korupsi). Unsur penyalahgunaan kewenangan Pasal 3 UU Tipikor bersifat alternatif, karena selain penyalahgunaan wewenang juga kesempatan dan sarana yang ada padanya karena jabatan adalah unsur tindak pidana korupsi. Penyalahgunaan kewenangan pada dasarnya merupakan perbuatan melawan hukum (dalam artian tindak pidana) harus 
disertai dengan adanya mens rea (berniat jahat). Bentuk konkret mens rea adanya actus reus berupa fraud, conflict of interest, dan illegality, sehingga merupakan tindak pidana. Sedangkan akibat dari penyalahgunaan wewenang dan sewenangwenang dalam ranah HAN adalah mengakibatkan keputusan pejabat tidak sah dan dapat dibatalkan (Nirwanto dalam Manao, 2018).

Merujuk pada uraian di atas, terdapat titik singgung antar HAN dan hukum pidana. Namun di sisi lain juga terdapat perbedaan antara HAN (UU No. 30 Tahun 2014 tentang Administrasi Pemerintahan dengan UU No. 20 Tahun 2001 tentang Pemberantasan Tindak Pidana Korupsi terutama terkait dengan frasa "penyalahgunaan wewenang" (Istilah dalam UU No. 30 Tahun 2014 tentang Administrasi Pemerintahan) dan "penyalahgunaan kewenangan" (Istilah dalam UU No. 20 Tahun 2001 tentang Pemberantasan Tindak Pidana Korupsi).

Berdasarkan uraian di atas dapat dipahami bahwa penyelesaian hukum penyalahgunaan wewenang oleh aparatur pemerintahan dari segi hukum administrasi dpat dihubungkan dengan tindak pidana korupsi yaitu sejak adanya UU No. 30 Tahun 2014 tentang Administrasi Pemerintahan. Penyelesaian hukum pidana tidak lagi menjadi pilihan pertama atau primum remedium. Secara prosedural berdasarkan Pasal 21 ayat (1) dan ayat (2) UU No.30 Tahun 2014 tentang Administrasi penyelesaian hukumnya terlebih dahulu diselesaikan PTUN. Jika terbukti dan telah berkekuatan hukum tetap, maka proses selanjutnya diselesaikan secara pidana berdasarkan Pasal 3 UU No. 20 Tahun 2001 tentang Pemberantasan Tindak Pidana Korupsi. Dalam konteks tersebut, hubungan penyelesaian hukum penyalahgunaan wewenang oleh aparatur pemerintahan dari aspek hukum administrasi merupakan prasyarat untuk diproses pidana.

\section{Penegakan Hukum Dalam Penanganan Tindak Pidana Korupsi Setelah Berlakunya UU No. 30 Tahun 2014 Tentang Administrasi Pemerintahan.}

Penegakan hukum merupakan suatu usaha untuk mewujudkan ide-ide keadilan, kepastian hukum dan kemanfaatan sosial menjadi kenyataan. Jadi penegakan hukum pada hakikatnya adalah proses perwujudan ide-ide. Penegakan hukum adalah proses dilakukannya upaya tegaknya atau berfungsinya norma-norma hukum secara nyata sebagai pedoman pelaku dalam lalu lintas atau hubunganhubungan hukum dalam kehidupan bermasyarakat dan bernegara. Penegakan hukum merupakan usaha untuk mewujudkan ide-ide dan konsep-konsep hukum yang diharapakan rakyat menjadi kenyataan (Shant, 2008).

Kebijakan penegakan hukum adalah usaha-usaha yang diambil oleh pemerintah atau suatu otoritas untuk menjamin tercapainya rasa keadilan dan ketertiban dalam masyarakat dengan menggunakan beberapa perangkat atau alat kekuasaan baik dalam bentuk undang-undang, sampai pada para penegak hukum antara lain polisi, hakim, jaksa, serta pengacara. Menurut Hamzah (2005), istilah penegakan hukum sering disalahartikan seakan-akan hanya bergerak di bidang hukum pidana atau di bidang represif. Istilah penegakan hukum disini meliputi baik yang represif maupun yang preventif. Jadi kurang lebih maknanya sama dengan istilah Belanda rechtshanhaving. Berbeda dengan istilah law enforcement, yang sekarang diberi makna represif; sedangkan yang preventif berupa pemberian informasi, persuasive, dan petunjuk disebut law compliance, yang berarti 
pemenuhan dan penataan hukum. Oleh karena itu lebih tepat jika dipakai istilah penanganan hukum atau pengendalian hukum.

Menurut Rahardjo (1987), penegakan hukum merupakan suatu usaha untuk mewujudkan ide-ide dan konsep-konsep menjadi kenyataan. Sedangkan menurut Soekanto (2002), secara konsepsional inti dari arti penegakan hukum terletak pada kegiatan menyerasikan hubungan nilai-nilai yang dijabarkan di dalam kaidahkaidah yang mantap dan sikap akhir untuk menciptakan, memelihara dan mempertahankan kedamaian pergaulan hidup.

Menurut Soekanto (2002) ada beberapa faktor yang mempengaruhi penegakan hukum dalam upaya penanggulangan kejahatan, yaitu:

1) Faktor hukumnya sendiri, yaitu ada kemungkinan terjadi ketidak cocokan dalam peraturan perundang-undangan mengenai bidang bidang kehidupan tertentu. Kemungkinan lainnya adalah ketidakcocokan antara peraturan perundang undangan dengan hukum tidak tertulis atau hukum kebiasaan. Kadangkala ketidakserasian antara hukum tertulis dan hukum kebiasaan dan seterusnya.

2) Faktor penegak hukum, yaitu salah satu kunci dari keberhasilan dalam penegakan hukum adalah mentalitas atau kepribadian dari penegak hukumnya sendiri. penegak hukum antara lain mencakup hakim, polisi, jaksa, pembela, petugas pemasyarakatan, dan seterusnya.

3) Faktor sarana atau fasilitas yang mendukung penegak hukum, yaitu seperti mencakup tenaga manusia yang berpendidikan dan terampil, organisasi yang baik, peralatan yang memadai, keuangan yang cukup. Kurangnya fasilitas yang memadai menyebabkan penegakan hukum tidak akan berjalan dengan semestinya.

4) Faktor masyarakat, yakni bagian yang terpenting dalam menentukan penegak hukum adalah kesadaran hukum masyarakat. Semakin tinggi kesadaran hukum masyarakat maka akan semakin memungkinkan penegakan hukum yang baik. Sebaliknya semakin rendah tingkat kesadaran hukum masyarakat, maka akan semakin sukar untuk melaksanakan penegakan hukum yang baik.

5) Faktor kebudayaan, yaitu budaya sebagai hasil karya, cipta, dan rasa yang di dasarkan pada karsa manusia dalam pergaulan hidup. Kebudayaan Indonesia merupakan dasar dari berlakunya hukum adat, sehingga berlakunya hukum tertulis (perundang-undangan) harus mencerminkan nilai-nilai yang menjadi dasar hukum adat.

Penegakan hukum pidana terdiri dari dua tahap inti yaitu penegakan hukum pidana in abstracto dan penegakan hukum pidana in concerto.

\section{Penegakan Hukum Pidana In Abstracto}

Penegakan hukum pidana in abstracto merupakan tahap pembuatan/perumusan (Tahap Formulasi) sudah berakhir saat diundangkannya suatu peraturan perundangundangan. Tahap legislasi/formulasi dilanjutkan ke tahap aplikasi dan tahap eksekusi. Dalam ketentuan perundang-undangan itu harus diketahui tiga masalah pokok hukum pidana yang berupa, yaitu: 
1) Tindak pidana (strafbaar feit/criminal act/actus reus)

2) Kesalahan (schuld/guit/mens rea)

3) Pidana (straf/punishment/poena)

Penegakan hukum pidana (PHP) merupakan bagian (sub-sistem) dari keseluruhan sistem/kebijakan penegakan hukum nasional, yang pada dasarnya juga merupakan bagian dari sistem/kebijakan pembangunan nasional. Kebijakan hukum pidana (penal policy), baik dalam arti PHP in abstracto maupun in concreto, merupakan bagian dari keseluruhan kebijakan sistem (penegakan) hukum nasional dan merupakan bagian dari upaya menunjang kebijakan pembangunan nasional (national development policy).

Sistem penegakan hukum pidana (SPHP) yang integral perlu dilihat secara in abstracto (law making and law reform) karena PHP in abstracto (pembuatan/perubahan undang-undang, law making/law reform) merupakan tahap pembuatan/perumusan (formulasi) undang-undang leh badan legislatif (dapat disebut tahap legislasi). Menurut Barda Nawawi Arief (2014), penegakan hukum in abstracto dilakukan dilakukan melalui legislasi/formulasi/pembuatan peraturan perundang-undangan. Proses legislasi/formulasi ini merupakan awal yang sangat strategis dari proses penegakan hukum in concreto.

SPHP yang ada pada saat ini belum integral secara in abstracto (law making and law reform) pada tahap proses pembuatan produk perundang-undangan. Karena belum adanya keterjalinan erat atau satu kesatuan sari sub-sistem (komponen) sistem norma/subtansi hukum pidana yang integral meliputi hukum pidana materiel, hukum pidana formal, dan hukum pelaksanaan pidana yang seharusnya integrated legal system atau integrated legal substance.

\section{Penegakan Hukum Pidana In Concreto}

Penegakan hukum pidana in concreto terdiri dari tahap penerapan/aplikasi (penyidikan) dan tahap pelaksanaan undang-undang oleh aparat penegak hukum, yang dapat disebut tahap judisial dan tahap eksekusi. Penegakan hukum pidana in concreto, pada hakikatnya merupakan proses penjatuhan pidana atau proses pemidanaan. Proses pemidanaan itu sendiri merupakan proses penegakan hukum pidana dalam rangka menegakkan kebenaran dan keadilan. kedua tahap itu merupakan aspek-aspek atau titik krusial dari penanganan dan penindakan suatu perkara pidana karena penegakan hukum pidana akan diwarnai sebagai berikut:

1) Masalah permainan kotor (perbuatan uang suap dan perbuatan tercela lainnya).

2) Masalah optimalisasi pendekatan keilmuan (scientific culture/approach) dalam penegakan hukum.

Penegakan hukum pidana pada tahap in concreto (tahap aplikasi) juga masih dipengaruhi oleh kebiasaan/budaya permainan kotor dan jalan pintas yang dilakukan oleh oknum aparat penegak hukum yang korup dan kolutif dengan pelaku tindak pidana. Barda Nawawi Arief (2014) menyatakan bahwa istilah permainan kotor lebih mengena dari pada mafia peradilan, karena hanya memberi kesan pada bentuk-bentuk perbuatan tercela yang terjadi selama proses pengadilan, padahal tidak sedikit keluhan masyarakat yang menjadi objek pemerasan dan perbuatan 
tercela/permainan kotor lainnya sebelum proses perkaranya dilimpahkan ke pengadilan.

Penegakan hukum itu kurang lebih merupakan upaya yang dilakukan untuk menjadikan hukum, baik dalam arti formil yang sempit maupun arti materiil yang luas, sebagai pedoman prilaku dalam setiap perbuatan hukum, baik oleh para subyek hukum yang bersangkutan maupun oleh aparatur penegakan hukum yang resmi diberi tugas dan kewenangan oleh Undang-undang untuk menjamin berfungsinya norma-norma hukum yang berlaku dalam kehidupan bermasyarakat dan bernegara. Masalah penegakan hukum menurut Rahadjo (1987) merupakan masalah yang rumit dikarenakan oleh sejumlah faktor yang mempengaruhi seperti:

1) Isi peraturan perundang-undangan;

2) Kelompok kepentingan dalam masyarakat;

3) Budaya hukum; dan

4) Moralitas para penegak hukum yang terlibat dalam proses peradilan.

Oleh karena itu penegakan hukum akan bertukar aksi dengan lingkungannya, yang bisa disebut sebagai pertukaran aksi dengan unsur manusia, sosial budaya, politik dan lain sebagainya. Untuk itu dalam menegakkan hukum ada tiga hal yang harus diperhatikan, yaitu kepastian hukum, kemanfaatan, dan keadilan. Berdasarkan hal tersebut di atas, dapat dikatakan bahwa fungsi penegakan hukum adalah untuk mengaktualisasikan aturan-aturan hukum agar sesuai dengan yang dicita-citakan oleh hukum itu sendiri, yakni mewujudkan sikap atau tingkah laku manusia sesuai dengan bingkai (frame work) yang telah ditetapkan oleh suatu undang-undang atau hukum.

\section{Kesimpulan}

Konsep penyalahgunaan wewenang dalam tindak pidana korupsi setelah berlakunya Undang-Undang Nomor 30 Tahun 2024 tentang Administrasi Pemerintahan adalah Penyalahgunaan kewenangan sesuai Pasal 17 UU No. 30 Tahun 2014, yaitu: larangan melampaui wewenang; larangan mencampuradukkan wewenang; dan/atau larangan bertindak sewenang-wenang. UU No. 30 Tahun 2014 fokus pada pencegahan penyalahgunaan wewenang, aspek tindak pidana korupsi terlebih dahulu dibuktikan berdasar hukum administrasi. Apabila ditemukan terjadinya penyalahgunaan wewenang yang memenuhi unsur dalam UU Tipikor maka dilakukan proses peradilan tindak pidana korupsi. Berdasarkan pengaturan UU No. 30 Tahun 2014 memungkinkan pembuktian adanya penyalahgunaan wewenang, sehingga proses penyelesaian tindak pidana korupsi berdasar UU Tipikor ditempuh setelah terbukti adanya penyalahgunaan wewenang yang dilakukan oleh PTUN. Dengan demikian terjadi pergeseran penyelesaian yang terlebih dahulu ditempuh penyelesaian berdasar hukum administrasi.

Pada proses penegakan hukum, apabila memang terjadi penyalahgunaan wewenang maka hal tersebut menjadi dasar oleh aparat penegak hukum untuk melakukan penyelidikan ataupun penyidikan dugaan tindak pidana korupsi terhadap pelaku penyalahgunaan wewenang. Sedangkan apabila di dalam pengujian terhadap penyalahgunaan wewenang oleh PTUN tidak terbukti maka barang tentu perbuatan tersebut tidak dapat dijadikan dasar untuk melakukan penyelidikan 
ataupun penyidikan terhadap pelaku penyalahgunaan kewenangan dalam tindak pidana korupsi berdasarkan Undang-Undang Republik Indonesia Nomor 20 Tahun 2001 tentang Perubahan atas Undang-Undang Republik Indonesia Nomor 31 Tahun 1999 tentang Pemberantasan Tindak Pidana Korupsi.

UU No. 30 Tahun 2014 tentang Administrasi Pemerintahan maupun UU No. 20 Tahun 2001 tentang Pemberantasan Tindak Pidana Korupsi tersebut tidak saling menegasikan (meniadakan) kewenangan masing-masing, dan tidak pula saling menunda kewenangan untuk melakukan pemeriksaan, sehingga muncul permasalahan mengenai pengadilan yang tepat untuk menilai ada atau tidak ada unsur penyalahgunaan wewenang yang dilakukan oleh Pejabat Pemerintah. Dengan demikian perlu pengaturan dalam memberikan kejelasan tahapan kewenangan kedua lembaga tersebut. UU No. 30 Tahun 2014 dapat menjadi patokan bagi penyidik KPK untuk tidak melakukan proses penyidikan terhadap terdakwa sebelum adanya putusan dari peradilan Tata Usaha Negara, mengingat kewenangan pejabat negara yang menjalankan tugasnya apabila melakukan pelanggaran maka kepada yang bersangkutan jika kasusnya masih dalam proses PTUN. KPK tidak dapat menahan terdakwa terlebih dahulu menunggu keluarnya putusan PTUN yang berkekuatan hukum tetap.

\section{DAFTAR KEPUSTAKAAN}

Adji, Indriyanto Seno (2009). Korupsi dan Penegakan Hukum. Cetakan Pertama. Jakarta: Diadit Media.

Arief, Barda Nawawi. (2014). Masalah Penegakan Hukum dan Kebijakan Hukum Pidana dalam Penanggulangan Kejahatan. Jakarta: Kencana.

Armono, Yudhi Widyo. (2014). Korupsi Karena Penyalahgunaan Wewenang. Proseding Seminar. Universitas Surakarta, http://ejournal.unsa.ac.id/ index.php/prosedingunsa/article/view/81.

Basah, Sjachran. (1985). Eksistensi dan Tolak Ukur Peradilan Administrasi di Indonesia. Bandung: Alumni.

Dinar, Chaerudin, Syaiful Ahmad dan Syarif Fadillah. (2009). Strategi Pencegahan dan Penegakan Hukum Tindak Pidana Korupsi. Bandung: Refika Aditama.

Hamzah, Andi. (2005). Asas-asas Penting dalam Hukum Acara Pidana. Surabaya: FH Universitas.

Ibrahim, Johny. (2007). Teori dan Metode Penelitian Hukum Normatif. Cetakan Ketiga. Malang, Jawa Timur: Banyumedia Publishing.

Manao, Disiplin F. (2018). Penyelesaian Penyalahgunaan Wewenang oleh Aparatur Pemerintah dari Segi Hukum Administrasi Dihubungkan Dengan Tindak Pidana Korupsi. Jurnal Wawasan Yuridika. Vol. 2, No. 1, Maret 2018.

Marzuki, Laica. (2017). Pemberlakuan Undang-Undang Nomor 30 Tahun 2014 tentang Administrasi Pemerintahan dalam Konteks Perkembangan 
Kompetensi Peradilan Tata Usaha Negara RI. Makalah disajikan dalam acara "Temu Karya Ilmiah Dalam Rangka HUT Peratun ke-26", Jakarta.

Nasution, S. (1992). Metode Penelitian Naturalistik Kualitatif. Bandung: Tarsito.

Nurjana, Igm. (2010). Sistem Hukum Pidana dan Bahaya Laten Korupsi. Jogjakarta: Pustaka Pelajar.

Rahardjo, Satjipto (1987). Masalah Penegakan Hukum. Bandung: Sinar Baru.

Shant, Dellyana. (2008). Konsep Penegakan Hukum. Yogyakarta: Liberty.

Soekanto, Soerjono. (2002). Faktor-faktor Yang Mempengaruhi Penegakan Hukum. Jakarta: Rajagrafindo Persada. 